Vol 41 (2016) No 184 333-347

\title{
Impact of Acculturative Stress and Social Support on Academic Adjustment of International Students
}

\author{
Ümit Cura ${ }^{1}$, Ayşe Negiş Işık ${ }^{2}$
}

\begin{abstract}
The aim of the study was to examine the relationship between academic adjustment, acculturative stress and perceived social support. The sample of the study consisted of 298 international students who were randomly selected among 1520 international students studying at four different universities in Turkey. The results of this study revealed that there were negative correlation between academic adjustment and acculturative stress, and positive correlation between academic adjustment and perceived social support. The results demonstrated that acculturative stress and perceived social support were significant predictors of academic adjustment of international students.
\end{abstract}

Keywords Internationalization

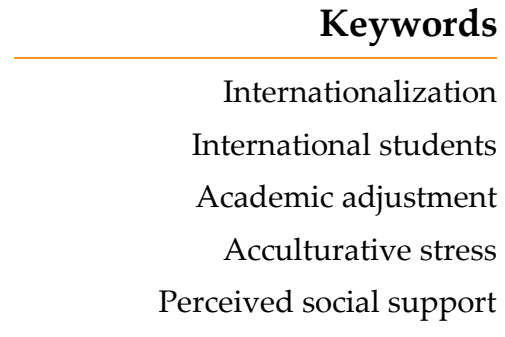

Article Info

Received: 30.11.2015

Accepted: 20.03.2016

Online Published: 27.04.2016

DOI: $10.15390 /$ EB.2016.6158

\section{Introduction}

Internationalization of higher education represents one of the transition processes of globalized and developing countries. Internationalization of higher education in Turkey has been contextualized in five dimensions by Çetinsaya (2014), particularly international students and faculty members. These dimensions are long and short-term international student and teaching staff mobility, sending Turkish students abroad for graduate studies, synchronizing Turkish higher education system with Bologna Process, establishing universities abroad in different countries, and establishing partner universities with other countries in Turkey.

As part of the internationalization process, accepting students to higher education institutions from different countries and cultures also brought along adjustment and acculturative issues. Scholars argued that international students may face common or different problems. It was determined that a large part of these issues derived from adjustment and acculturative problems such as cultural distance, self-efficacy, language proficiency, financial problems, cultural differences, discrimination and racism, stress, orientation, family and friend support etc. (Özoğlu, Gür, \& Coşkun, 2012). These problems faced by international students are the primary factors affecting academic adjustment and success (Berry, 1987; Berry, 1997; Li, Chen, \& Duanmu, 2009; Misra, Crist, \& Burant, 2003; Poyrazll, Kavanaugh, Baker \& Al-Timimi, 2004; Sümer, Poyrazlı, \& Grahame, 2008; Ward \& Kennedy, 1995; Ye, 2006; Yeh \& Inose, 2003). It is an undeniable fact that international students studying at higher education institutions in Turkey also have adjustment and acculturative problems. There are limited studies that deals with this

\footnotetext{
${ }^{1}$ Mevlana University, Graduate Institute for the Social Science, Educational Administration, Supervision, Planning and Economics Department, Turkey, ucura@mevlana.edu.tr

${ }^{2}$ Mevlana University, Faculty of Education, Educational Sciences Department, Turkey, anegis@mevlana.edu.tr
} 
topic in national literature, so this situation makes this study important. This is a descriptivecorrelational study that examines the relationship among academic adjustment, acculturation stress and social support of international students.

\section{Academic Adjustment}

International students at higher education have to face with adapting process to new social and academic environment. Generally, the concept of adjustment can be defined as a dynamic and interactive multifaceted complex process in which the people try to establish a positive relationship with their environment (Anderson, 1994). International students need to adapt to the culture of host country and academic environment which contains a new language and study habits. The concept of academic adjustment can be defined as adapting to the school environment and having success in academic context on teaching process (Ramsay, Barker, \& Jones, 1999).

There are many studies that examine the variables of academic and socio-cultural adjustment of international students (Berry, 1997; Campbell, 2012; Cownie \& Addison, 1996; Gerdes \& Mallinckrodt, 1994; Glover, 2011; Li et al., 2009; Yeh \& Inose, 2003; Yuan, 2010; Yusoff, 2011; Zhang, 2012). Although the majority of these studies conducted in the United States and European countries, together with increasing the number of international students in Asian countries including Turkey has led to begin researches in this issue (Can, 1996; Otlu, 2010; Özçetin, 2013; Yusoff, 2011; Zhang, 2012).

One of the variables affecting academic and cultural adjustment of international students is language. It was observed that having the command of host country's language increased the academic success (Hau \& Salili, 1996; Wardlow, 1999) and academic adjustment levels of international students (Li et al., 2009; Sawir, Marginson, Forbes-Mewett, Nyland, \& Ramia, 2012). The language of host country is not only medium of education but also is the language of communication with necessary institutions (municipality, hospital, dormitory etc.) for sustaining the socialization and life. Therefore, international students get less stress with increasing the command of language (Lee, 1997; Lin \& Yi, 1997; Malcolm \& McGregor, 1995; Nasrin, 2001).

The other variables affecting academic and cultural adjustment of international students are the demographic characteristics. European female students studying at United States universities solved their problems more easily than female students from other regions, such as prejudice, loneliness, homesickness and making friends (Güçlü, 1996). On the other hand, Asian, African, Indian, Latin American and Middle Eastern international students studying at European universities were faced with problems related to making friends (Mori, 2000) and discrimination (Lee \& Rice, 2007; Poyrazlı \& Lopez, 2007). Shortly, these students have less social and academic adjustment levels because of having higher level of acculturative stress than other international students (Yeh \& Inose, 2003).

There are a few studies which investigate the relationship between international students' academic adjustment and acculturation stress levels in terms of age and gender variables. These studies reveal different results from each other. Sodowsky and Plake (1992), Yeh and Inose (2003) reached that gender was not a significant predictor of acculturative stress, but Gilbert and Scher (1999), Poyrazli, Arbona, Nora, McPherson, and Pisecco (2002) reached just the opposite results. Male international students were more stressed than female international students because of the conflicts that female international students showed more behavioral and psychological reactions under academic stress (Misra \& Castillo, 2004). Yeh and Inose (2003), Poyrazlı et al., (2004) concluded that age was not a significant predictor of acculturative stress levels of international students. However, Ye (2006) found that elder international students had more lower acculturative stress than younger students. 


\section{Acculturation and Acculturative Stress}

The concept of acculturation, which was used at the first time in history by Plato and conceptualized within the framework of cross-cultural psychology and anthropology in 1880 (Nahavandi \& Malekzadeh, 1988; Rudmin, 2003), was described in 1935 by the Social Science Research Council as the following: "Acculturation comprehends those phenomena which result when groups of individuals having different cultures come into continuous first-hand contact, with subsequent changes in the original cultural patterns of either or both groups" (Redfield, Linton \& Herskovits, 1936, p. 149).

In the professional literature, the number of study and analysis on acculturation quietly increased in the second half of the $20^{\text {th }}$ century. This concept was defined as cross-cultural and psychological change process which occurred between two or more cultural groups and their members (Berry, 1992, 1997, 2005, 2006; Berry, Kim, Minde, \& Mok, 1987; Williams \& Berry, 1991).

Higher education students' adaptation to college life can be a stressful process. Students who choose a different country for their higher education are faced with cultural and psychological changes. It is an inevitable fact that international students were faced with different types of life stress because of interacting with each other and students of home country. Acculturative stress can be defined as the experienced stress for different reasons in the acculturation process occurring between two different cultures (Berry, 2005; Berry \& Annis, 1974; Nilsson, Butler, Shouse, \& Joshi, 2008).

The stress and adjustment model of acculturation was developed by Berry $(1987,2006)$ determining borders of stress and coping models in explaining the factors which affects acculturative stress and cultural adjustment. In this model, Berry (1997) conceptualized the acculturation experience which contains a number of changes and important life events.

Acculturative stress is a phenomenon that occurs in the process of adapting to a new culture of the individuals or groups. The level of stress varies according to the differences or similarities between home and host cultures. Berry et al. (1987) collected the factors of acculturative stress in five groups: nature of the larger society, type of acculturating group, modes of acculturation, demographic and social characteristics of individual, psychological characteristics of individual. These factors include personal characteristics, education level, knowledge and skills, gender, age, language and race variables together with psychological and spiritual states. In addition, the attitude of host country and its society was an important factor affecting the stress level of host culture (Cox, Holden, \& Sagovsky, 1987). When family, friend and school support factors are combined with the support of the host society, the concept of social support occurs. Many variables affect the level of acculturative stress that the concept of social support is one of the primary factors affecting the stress level (Hayes \& Lin, 1994; Pedersen, 1991).

\section{Social Support}

Social support is defined as "help that would be available to an individual in difficult or stressarousing situations" (Sarason \& Sarason, 1982, p. 331) which refers to one of the coping skills and help when needed.

The concept of social support is related to many personal, environmental and cultural factors; it is considered to be non-permanent in social networks. It is associated with the execution of personal relationships in natural environment. In fact, this relationship assigns a supportive meaning on behavior, and supportive behaviors can bring meaningful relationship to the interaction (Gottlieb \& Bergen, 2010).

Hale, Hannum, and Espelage, (2005) expressed the concept of social support as "consisting of a number of different domains, including emotional support, appraisal and affirmation, informational assistance, intimacy, comfort, and physical affection" (p. 276). When a new member of the organization need any matter, helping him/her refers to the role of social support.

It was determined that there was a direct proportional relationship between social support and coping skills. Furnham and Shiekh (1991) stated that social support plays an important role in the 
process of acculturation and trusting to the society. Coffman and Gilligan (2003) found that students with high level of social support had higher level coping ability in the university environment.

Graduating from high school in their countries and beginning higher education in another country is a major life change for international students. Along with university life, students obtain significant opportunities for academic experience and psychological development. Besides, they may face with some difficulties and acute stress. In this process, academic demands increase and new social relations are established. Because of departing from their home countries and cultures, their relationship with their families and friends decreases, and they lose support as a result. This circumstance leads to stress and increase psychological maladjustment and reduction of academic adjustment in higher education (Gall, Evans, \& Bellerose, 2000; Hayes \& Lin, 1994; Pedersen, 1991; Tao, Dong, Pratt, Hunsberger, \& Pancer, 2000).

Hammer (1992) investigated the correlation between communication and adjustment, and he revealed that international students needed to communicate with host society to ensure academic adjustment. Several studies found out that, social support positively affects the acculturation process of international students (Al-Sharideh \& Goe, 1998; Poyrazlı et al., 2004; Yang, Noels, \& Saumure., 2005; Yusoff \& Chelliah, 2010). Ward and Kennedy (1999) found that there was positive correlation between coping skills, adjustment, social acceptance and social support. As a result of study in social support field, Black (1989) explored that the role of social support played by receiving country students built a bridge between cultural adjustment and academic success of international students.

\section{Purpose of the Study}

When the relevant literature was examined, it was observed that there were many international studies, but very few national studies about acculturative stress and social support on academic adjustment of international students. When the national literature was examined, studies of Can (1996), Pirliyev (2010), Otlu (2010) and Özçetin (2013) were achieved. So, it was found that acculturative stress and social support were significant predictors of international students' academic adjustment. When these effects are considered, describing the acculturation strategies and social support in detailed will play an important role in ensuring the academic adjustment of these students, and also these effects are considered to guide to managers, academicians and consultants.

The purpose of this study is to examine the relationship between academic adjustment level, acculturation stress and perceived social support of international students. For this purpose it has been sought answers to the following questions:

- Is there significant relationship between academic adjustment, acculturative stress and social support in perceptions of international students?

- Do acculturative stress and perceived social support predict academic adjustment? 


\section{Method}

\section{Research Design}

This paper is a descriptive-correlational study to examine the relationship between academic adjustment, acculturation stress and social support of international students at higher education institutions. In this study, the impacts of acculturative stress and social support were investigated on academic adjustment. Within this context, dependent variable is academic adjustment, and a set of independent variables are acculturative stress and perceived social support.

\section{Participants}

The participants of the study consists of 298 international students from five different continents and 61 different countries studying at four universities, in the academic year 2013-2014. The data was collected by taking the necessary permission from the universities. The demographic variables of the participants are given in Table 1.

Table 1. Demographic Variables of Participants

\begin{tabular}{|c|c|c|c|}
\hline Variables & Category & $f$ & $\%$ \\
\hline \multirow{2}{*}{ Gender } & Female & 73 & 24,5 \\
\hline & Male & 225 & 75,5 \\
\hline \multirow{6}{*}{ Region } & Turkic Republics & 78 & 26,2 \\
\hline & Europe & 26 & 8,7 \\
\hline & Africa & 114 & 38,3 \\
\hline & Middle East & 43 & 14,4 \\
\hline & Asia & 35 & 11,7 \\
\hline & America & 2 & 0,7 \\
\hline \multirow{2}{*}{ Education Level } & Graduate & 39 & 13,1 \\
\hline & Undergraduate & 259 & 86,9 \\
\hline \multirow{5}{*}{ Grade } & 1 (freshman) & 107 & 35,9 \\
\hline & 2 (sophomore) & 75 & 25,2 \\
\hline & 3 (junior) & 46 & 15,4 \\
\hline & 4 (senior) & 38 & 12,8 \\
\hline & Other & 32 & 10,7 \\
\hline \multirow{6}{*}{ Accommodation } & Dormitory & 130 & 43,6 \\
\hline & Rented House & 127 & 42,6 \\
\hline & Fraternity or Sorority House & 21 & 7 \\
\hline & Own House & 6 & 2 \\
\hline & Family House & 12 & 4 \\
\hline & Other & 2 & 0,7 \\
\hline \multirow{3}{*}{ Education Level of Family } & $1^{\text {st }}$ generation college student & 144 & 48,3 \\
\hline & $2^{\text {nd }}$ generation college student & 109 & 36,6 \\
\hline & $3^{\text {rd }}$ generation college student & 45 & 15,1 \\
\hline \multirow{6}{*}{ Educational Financing } & Financial Support (Scholarship) & 71 & 23,8 \\
\hline & Savings and trust funds & 19 & 6,4 \\
\hline & Employment & 2 & 0,7 \\
\hline & Family Support & 144 & 48,3 \\
\hline & Loans & 46 & 15,4 \\
\hline & Other & 16 & 5,4 \\
\hline
\end{tabular}


Table 1. Continue

\begin{tabular}{llcc}
\hline Variables & Category & $f$ & $\mathbf{\%}$ \\
\hline Scholarship & Yes & 125 & 41,9 \\
& No & 173 & 58,1 \\
& $3.50-4.00$ & 35 & 11,7 \\
& $3.00-3.49$ & 72 & 24,2 \\
General Point Average & $2.50-2.99$ & 78 & 26,2 \\
& $2.00-2.49$ & 70 & 23,5 \\
& $1.50-1.99$ & 32 & 10,7 \\
& $1.00-1.49$ & 11 & 3,7 \\
Age & $1.00-0.00$ & - & - \\
& & Average & Ranj \\
& & 21.5 & $17-36$ \\
\hline
\end{tabular}

According to distribution of students by gender variable, 225 (75.5\%) of the participants were male and $73(24.5 \%)$ were female. It was seen that the majority of participants were male students. When looking at distribution of students according to their regions (Turkic Republics and Middle Eastern Countries are also classified) it was seen that $78(26,2 \%)$ of the participants were from Turkic Republics (5 countries), 26 (8,7\%) of the participants were from European countries (11 countries), 114 (38,3\%) of the participants were from African countries (23 countries), $43(14,4 \%)$ of the participants were from Middle Eastern countries ( 7 countries), 35 (11,7\%) of the participants were from Asian countries (12 countries), 2 ( $0,7 \%)$ of the participants were from America ( 2 countries).

Different education and grade levels of students were included in the present study. In the sample, each of the three cycles of higher education was well-represented that $259(87 \%)$ of the participants were undergraduate students and $39(13 \%)$ were graduate students: $107(36 \%)$ freshmen, $75(25 \%)$ sophomores, $46(15 \%)$ juniors, $38(13 \%)$ seniors, and $32(11 \%)$ graduate students. The age of the participants ranged from 17 to 36 with a mean of 21.5.

Considering the residence of students, majority of them were living at dormitories (44\%) and rental houses (43\%). Students also were asked how they afforded the education fee, and whether they received the scholarship or not. $64 \%$ of students stated that their families afforded the education fee, and $15 \%$ of students reported that their parents took out loan to afford the education fee. $42 \%$ of students were receiving scholarship, and the remaining were not.

\section{Data Collection Instruments}

\section{Adjustment Inventory}

Adjustment Inventory was originally developed by Srivastava and Tiwari (1972) in order to determine the general adjustment level of graduate and undergraduate students. The original language of the scale is English. The questionnaire consists of 80 items and has four subscales: home, educational, emotional and social areas of adjustment. The inventory consists of "Yes" or "No" type of items. The reliability coefficient have been found by Kuder Richardson formula 20, and coefficients ranged from .91 to .95 for the total scale. The coefficient varies between .87 to .89 for home, .87 to .96 for emotional, .83 to .89 for educational, .90 to 94 for social and .91 to .95 for the total inventory on the three methods. The inventory was validated against the adjustment inventory by Sinha and Singh, $r=.70(\mathrm{~N}=200)$ and the adjustment inventory by Mittal, $r=.73(\mathrm{~N}=150)$.

The educational sub-scale consisting of 18 items was only used in this study, and the reliability coefficient recalculated and found .63 for this sub-scale.

Acculturative Stress Scale for International Students

Acculturative Stress Scale for International Students was originally developed by Sandhu and Asrabadi (1994) in order to determine the acculturative stress level of international students. The 
questionnaire consists of 36 items and has six sub-scales: perceived discrimination, homesickness, perceived hate, fear, stress due to change/culture shock and guilt. It is a Likert type questionnaire and responses change from 1 to 5, $1=$ strongly disagree, $2=$ disagree, $3=$ not sure, $4=$ agree, and $5=$ strongly agree. The total score for the scale ranges from 36 to 180 . Higher scores indicate greater acculturative stress by the students.

As a result of exploratory factor analysis which tested the construct validity of the scale by Sandhu and Asrabadi (1994), the questionnaire consist of 6 sub-scales, and these sub-scales explain $67.5 \%$ of the total variance. The alpha levels for the sub-scales are: perceived discrimination (.64-.80), homesickness (.69-.86), perceived hate (.67-.91), fear (.65-.78), stress due to change/culture shock (.61$.70)$ and guilt (.62-.79). The other ten question which were not included in any sub-scale was classified as "other" by researches. These questions were related to the acculturative stress variables that they were included in the scale. They were not subject to assessment in the present study since the analysis was based on 26 questions in total.

Researchers did not provide any information of the reliability of scale in the relevant article. In the present study, in order to determine the internal consistency reliability of the scale, the Cronbach alpha reliability coefficient of both total scale and sub-scales were calculated. The Cronbach alpha found .86 for the total scale, .85 for the perceived discrimination, .65 for the homesickness, .82 for the perceived hate, .69 for the fear, .64 for the stress due to change/culture shock and .62 for the guilt.

\section{Multidimensional Scale of Perceived Social Support}

The Multidimensional Scale of Perceived Social Support was developed by Zimet, Dahlem, Zimet, and Farley (1988) in order to determine the significance of the social support of international students receiving from family, friends and others. It is a 7 point Likert type scale with 12 items that it has three sub-scales. The original language of the scale is English. The responses change from 1 to $7,1=$ strongly disagree and $7=$ strongly agree.

According to result of exploratory factor analysis testing the validity of the scale structure by Zimet et al. (1988), a principal components analysis identified three factors that together accounted for 83.9 of the variance. Zhang (2012) replaced the four items measuring perceived social support from significant others with another 3 items dealing with social support from international student offices and international student clubs of universities.

The exploratory factor analysis for the modified version of the MSPSS was conducted and revealed three factors that the total variance explained by the model as a whole was $67.5 \%$. For internal reliability of current study, Cronbach alpha coefficient was calculated .94 for the total scale, .88 for the family support sub-scale, .96 for the friend support subscale, and .96 for the university support subscale.

\section{Data Collection and Analyses Procedures}

The current study was conducted in the fall and spring semesters of 2013-2014 academic year. The data was collected by taking the necessary permission from the universities.

In the current study, SPSS (Statistical Package for the Social Sciences) 15 was used in analyzing data, and also mean, standard deviation, Pearson Moment Correlation and multiple regression analysis were calculated. 


\section{Results}

The purpose of the present study is to investigate the relationship between academic adjustment level, acculturation stress and perceived social support of international students in higher education. In this section, the findings of this study are presented considering the sub-problems.

The academic adjustment was significantly and negatively correlated at low level with perceived discrimination $(\mathrm{r}=.271)$ and hate $(\mathrm{r}=.231)$ which are sub-scales of acculturative stress. It was found that there was a negative correlation between academic adjustment and other sub-scales of acculturative stress, but these relationships were not statistically significant. Considering these results, it can be concluded that international students' academic adjustment levels decrease when the acculturative stress level increase.

The relationship between academic adjustment and perceived social support was also examined in the present study. As shown in Table 3, academic adjustment was significantly and positively correlated at weak correlation with family support $(r=.145)$, friend support $(r=.268)$ and school support $(\mathrm{r}=.215)$. These findings indicate that as the perceived family, friend and school support increase, academic adjustment level increases.

When the correlation between perceived social support and sub-scales of acculturative stress was examined, it was seen that perceived discrimination was significantly and negatively correlated with friend support $(r=-.169)$ and school support $(r=-.318)$. This finding indicated that receiving support from school increased the level of perceived discrimination of international students. It was found that hate was significantly and negatively correlated at low and medium level with family support $(r=-.125)$, friend support $(r=-.171)$ and school support $(r=-.301)$. Similar to previous findings, receiving support from school increases the level of perceived hate of international students.

The correlation between school support and perceived cultural shock was significant and negative at weak correlation. When these results are generally considered, it can be concluded that international students' acculturative stress level is correlated with perceived social support, especially receiving school support decreases the level of acculturative stress.

In the present study, multiple regression analysis is used in order to determine the impact of acculturative stress and perceived social support on academic adjustment of international students. The results of analysis are given in Table 2.

Table 2. Results of Multiple Regression Analysis for the Predictors of Academic Adjustment

\begin{tabular}{lccc}
\hline & $\boldsymbol{\beta}$ & $\mathbf{t}$ & $\mathbf{p}$ \\
\hline Acculturative Stress & -.44 & 8.90 & .000 \\
Social Support & .28 & 5.67 & .000 \\
\hline
\end{tabular}

$R^{2}=.27 F=55,181 p=.000$

As indicated in Table 2, the model, to determine the acculturative stress and social support as predictors of academic adjustment, was significant $(R 2=.27, F=55,181 p=.000)$. These two variables explain $27 \%$ of the variance related to academic adjustment. When standardized regression coefficients are considered, it can be said that acculturative stress is more important than social support on academic adjustment. Looking at the $t$ values for the significance of the regression coefficients, it was seen that both acculturative stress $(t=8.90, p=.000)$ and social support $(t=5.67, p=.000)$ had a significant impact on explaining of academic adjustment. 


\section{Discussion}

In the present study, it was investigated the relationship between academic adjustment level, acculturation stress and perceived social support of international students. It was also aimed to determine whether the academic adjustment as a significant predictor of acculturative stress and social support or not.

According to results of this research, academic adjustment was significantly and negatively correlated with sub-scales of acculturative stress, especially hate and perceived discrimination. When standardized regression coefficients are considered, it can be said that acculturative stress is more important than social support on academic adjustment. Looking at the $t$ values for the significance of the regression coefficients, it was seen that both acculturative stress $(t=8.90, p=.000)$ and social support $(t=5.67, p=.000)$ had a significant impact on explaining of academic adjustment. The results of this study show that acculturative stress decreases academic adjustment of international students. Sandhu and Asrabadi (1994), Yeh and Inose (2003), Hanassab (2006), Poyrazl1, Thukral, and Duru (2010) revealed that acculturative stress was significantly and positively correlated with perceived and hate. Results of these studies support the current study.

Otlu (2010) investigated the role of gender, acculturative stress, coping skills, cultural distance, and perceived social support in predicting college adjustment scores of international students. The results of the study revealed that there was a significantly negative correlation between college adjustment and acculturative stress. So, acculturative stress was significant predictor of college adjustment scores of international students while perceived social support was not.

It was observed that academic adjustment was significantly and positively correlated with family support, friend support and school support in this current study. So, it can be said that receiving support from family, friends and school in high level increases the academic adjustment level of international students. Acculturative stress of international students is related to perceived social support, especially receiving school support has an effect on decreasing the acculturative stress.

Yeh and Inose (2003) found that acculturative stress scores of international students was change depending on their culture, language, social cohesion and perceived social support. This result shows that perceived social support was a significant predictor of academic adjustment.

Zhang (2012) reached that perceived social support of international students was the predictor of acculturative stress and depression. It was also found that international students who had high level of acculturative stress, also had high level of depression. Accordingly, international students having high level of acculturative stress have low level of academic adjustment. According to Berry et al. (1987), if acculturative stress level increases, adverse effects may occur which affect the person's psychological health and cause depression. Communicating with host society was significantly and negatively correlated with acculturative stress $(r=-.33)$ that this correlation supports the result of current study. International students having low level acculturative stress had high level of academic adjustment. 
Table 3. Correlation Analysis Results Between Academic Adjustment, Acculturation Stress and Perceived Social Support

\begin{tabular}{|c|c|c|c|c|c|c|c|c|c|c|c|c|}
\hline & $\bar{x}$ & Ss & 1 & 2 & 3 & 4 & 5 & 6 & 7 & 8 & 9 & 10 \\
\hline $\begin{array}{l}\text { 1. Academic } \\
\text { Adjustment }\end{array}$ & 30,30 & 2,69 & & & & & & & & & & \\
\hline $\begin{array}{l}\text { 2. Perceived } \\
\text { Discrimination }\end{array}$ & 27,36 & 9,84 &,$- 271^{* *}$ & & & & & & & & & \\
\hline 3. Homesickness & 12,22 & 4,24 &,- 037 &, $366^{* *}$ & & & & & & & & \\
\hline 4. Hate & 10,71 & 4,40 &,$- 231^{* *}$ & $677^{* *}$ & $251^{* *}$ & & & & & & & \\
\hline 5. Fear & 8,69 & 3,13 &,- 082 &, $407^{* *}$ & $175^{* *}$ &, $350^{* *}$ & & & & & & \\
\hline 6. Cultural Shock & 6,99 & 2,86 &,- 100 &, $507^{* *}$ & $274^{* *}$ & $444^{* *}$ & $408^{* *}$ & & & & & \\
\hline 7. Guilt & 4,50 & 2,05 & ,002 &, $367^{* *}$ &, $221^{* *}$ &, $368^{* *}$ & $232^{* *}$ &, $384^{* *}$ & & & & \\
\hline 8. Family Support & 23,05 & 4,38 & $145^{*}$ &,- 090 & ,110 &,$- 125^{*}$ &,$- 124^{*}$ &,- 030 & ,038 &,- 046 & & \\
\hline 9. Friend Support & 21,20 & 4,97 & $268^{* *}$ &,$- 169^{* *}$ & 075 &,$- 171^{* *}$ &,- 067 &,- 081 &,- 102 &,- 077 & $468^{* *}$ & \\
\hline 10. University Support & 14,42 & 4,77 &, $215^{* *}$ &,$- 318^{* *}$ &,- 058 &,$- 301^{* *}$ &,- 058 &,$- 141^{*}$ &,- 099 &,$- 167^{* *}$ &, $192^{* *}$, &, $469^{* *}$ \\
\hline
\end{tabular}

Lee and Çiftçi (2014) conducted a study to determine the effects of multicultural personality, self-confidence, social support and academic self-efficacy on socio-cultural adaptation of Asian international students studying at universities of United States. Multicultural personality and selfconfidence was positively correlated with socio-cultural adaptation. The multicultural personality was positively correlated with social support. However, social support was not directly affect the sociocultural adaptation.

In this current study, it was concluded that acculturative stress levels of international student $(\mathrm{t}=8.90, \mathrm{p}=.000)$ and perceived social support $(t=5.67, p=.000)$ were predictors of academic adjustment. It can be said that acculturative stress is more important than social support on academic adjustment.

Chavajay and Skowronek (2008) investigated the factors which affected the acculturative stress level of international students studying at universities of Utah, United States. Students from 33 different countries were included in this study: Asia (77.7\%), South America (9.2\%), Europe (7.7\%) and Africa (5.4\%). It was revealed that perceived discrimination, loneliness and academic anxiety were predictors of acculturative stress, and acculturative stress was the predictor of academic adjustment.

Nasir (2012), who concluded that acculturation was effective in the academic achievement of international students, revealed that students with high scores in cultural adaptation scale had high GPA. This result was supported by Chen, Rubin and $\mathrm{Li}$ (1997) that acculturative stress was the predictor of academic adjustment according to these two studies.

Cownie and Addison (1996) concluded that English language supporting centers at universities contributed to international students in communication with domestic and other students, and also provided to the success of their education. Shortly, language support means "only support". If international students were getting language support, their acculturative stress scores were low, and academic adjustment scores were high. Language proficiency of international students studying in the host country's language has an impact on academic achievement. In addition, communication of students with their friends and academicians is in the same line with academic adjustment (Bayliss \& Raymond, 2004).

Poyrazli et al. (2004) studied to detect the role of gender, age, social networking features, race, social support and English proficiency determining the level of acculturative stress of international higher education students, and found that international students having English language proficiency and high level social support faced with low level acculturative stress. So, perceived social support was the predictor of acculturative stress. 


\section{Conclusion and Suggestions}

According to results of this study, acculturative stress and perceived social support levels of international students were found to be the significant predictors of their academic adjustment. Academic adjustment was significantly and positively correlated with perceived social support, and negatively correlated with acculturative stress. This study has shown the following: when international students have a low level of acculturative stress, they have a high level of academic adjustment. Besides, if they perceive a high level of social support, their academic adjustment levels increase.

Within the scope of the internalization of higher education institutions, international students have an important position in this process. When this point is taken in consideration, higher education institutions should determine their own policies which include admitting of international students and employing them in a job. It is especially important to support students in term of academic adjustment. It is considered that various studies and activities can be conducted to increase friends and school support. At universities, the founding of international student offices and clubs will positively affect the academic adjustment of international students.

The results of this study show the impact of school support on academic adjustment of international students. However, there are some limitations of this study that English form of the scale was used, because sampling students' Turkish language proficiency were different from each other. Besides, these students' English language proficiency were varied. In data collection process, the researcher helped students to fill out the questionnaire, and tried to explain incomprehensible questions. Another limitation of this study is that the reliability of Adjustment Inventory is .60. Results of this study, however, can play an important role to increase academic adjustment levels of international students. 


\section{References}

Al-Sharideh, K. A., \& Goe, W. R. (1998). Ethnic community within the university: An examination of factors influencing the personal adjustment of international students. Research in Higher Education, $39,699-725$.

Anderson, L. E. (1994). A new look at an old construct: Cross-cultural adaptation. International Journal of Intercultural Relations, 18, 293-32.

Bayliss, D., \& Raymond, P. M. (2004). The link between academic success and L2 proficiency in the context of two professional programs. The Canadian Modern Language Review, 61(i), 29-51.

Berry, J. W. (1987). The Comparative Study of Cognitive Abilities. In S. H. Irvine, \& S. Newstead (Eds.), Intelligence and Cognition: Contemporary Frames of Reference (pp. 393-420). Dordrecht: Nijhoff.

Berry, J. W. (1992). Acculturation and adaptation in a new society. International Migration, 30, 69-85.

Berry, J. W. (1997). Immigration, acculturation and adaptation. Applied Psychology: An International Review, 46(1), 5-68.

Berry, J. W. (2005). Acculturation: Living successfully in two cultures. International Journal of Intercultural Relations, 29, 697-712.

Berry, J. W. (2006). Stress perspectives on acculturation. In D. L. Sam, \& J. W. Berry (Eds.), The Cambridge Handbook of Acculturation Psychology (pp. 43-57). Cambridge: Cambridge University Press.

Berry, J. W., \& Annis, R. C. (1974). Acculturative stress: The role of ecology, culture and differentiation. Journal of Cross-Cultural Psychology, 5, 382-406.

Berry, J. W., Kim, U., Minde, T., \& Mok, D. (1987). Comparative studies of acculturative stress. International Migration Review, 21, 491-511.

Black, J. S. (1989). Locus of control, social support, stress and adjustment in international transfers. Pacific Journal of Management, 7, 1-29.

Campbell, N. (2012). Promoting intercultural contact on campus: A project to connect and engage international and host students. Journal of Studies in International Education, 16, 205-227.

Can, N. (1996). Türkiye'de yükseköğrenim gören yabancı uyruklu öğrencilerin sorunları ve örgütsel yapı. Erciyes Üniversitesi Sosyal Bilimler Enstitüsü Dergisi, 7, 503-512.

Chavajay, P., \& Skowronek, J. (2008). Aspects of acculturation stress among international students attending a university in the USA. Psychological Reports, 103, 827-835.

Chen, X., Rubin, K. H., \& Li, B. (1997). Maternal acceptance and social and school adjustment in Chinese children: A four-year longitudinal study. Merrill-Palmer Quarterly, 43, 663-681.

Coffman, D. L., \& Gilligan, T. D. (2003). Social support, stress, and self-efficacy: Effects on students' satisfaction. Journal of College Student Retention, 4, 53-66.

Cownie, F., \& Addison, W. (1996). International students and language support: a new survey, studies in higher education. Studies in Higher Education 21(2), 221-231.Cox, J. L., Holden, J. M., \& Sagovsky, R. (1987). Detection of postnatal depression. Development of the 10-item Edinburgh Postnatal Depression Scale. The British Journal of Psychiatry, 150(6), 782-786.

Çetinsaya, G. (2014). Büyüme, kalite, uluslararasılaşma: Türkiye yükseköğretimi için bir yol haritası. Eskişehir: Anadolu Üniversitesi Basımevi Müdürlüğü.

Furnham, A., \& Shiekh, S. (1991). Gender, generation and social support correlates of mental health in Asian immigrants. International Journal of Social Psychiatry, 39, 23-33.

Gall, T. L., Evans, D. R., \& Bellerose, S. (2000). Transition to first-year University: Patterns of change in adjustment across life domains and time. Journal of Social and Clinical Psychology, 19, 544-567.

Gerdes, H., \& Mallinckrodt, B. (1994). Emotional, social, and academic adjustment of college students: A longitudinal study of retention. Journal of Counselling and Development, 72(3), 281-288. 
Gilbert, L. A., \& Scher, M. (1999). Gender and Sex in Counseling and Psychotherapy. Needham Heights, MA: Allyn \& Bacon.

Glover, P. (2011). A comparison between domestic and international students' trip characteristics: evidence from an Australian university. Journal of Vacation Marketing, 17(4), 263-274.

Gottlieb, B. H., \& Bergen A. E. (2010). Social support concepts and measures. Journal of Psychosomatic Research 69, 511-520.

Güçlü, N. (1996). Yabancı öğrencilerin uyum problemleri. Hacettepe Üniversitesi Ĕ̆itim Fakültesi Dergisi, 12, 101-110.

Hale, C. J., Hannum, J. W., \& Espelage, D. L. (2005). Social support and physical health: the importance of belonging. Journal of American College Health, 53, 276-284.

Hammer, M. R. (1992). Research, mission statements, and international student advising offices. International Journal of Intercultural Relations, 16(2), 217-236.

Hanassab, S. (2006). Diversity, international students, and perceived discrimination: implications for educators and counselors. Journal of Studies in International Education, 10, 157-172.

Hau, K. T., \& Salili, F. (1996). Prediction of academic performance among Chinese students: Effort can compensate for lack of ability. Organizational Behavior and Human Decision Processes, 65, 83-94.

Hayes, R. L., \& Lin, H. R. (1994). Coming to America: Developing social support systems for international students. Journal of Multicultural Counseling and Development, 22, 7-16.

Lee, D. (1997). What teachers can do to relieve problems identified by international students. New Directions for Teaching and Learning, 70, 93-100.

Lee, J., \& Çiftçi, A. (2014). Asian international students' socio-cultural adaptation: Influence of multicultural personality, assertiveness, academic self-efficacy, and social support. International Journal of Intercultural Relations, 38(1), 97-105.

Lee, J. J., \& Rice, C. (2007). Welcome to America? International student perceptions of discrimination. Higher Education, 53, 381-409.

Li, G., Chen, W., \& Duanmu J-L. (2009). Determinants of international students' academic performance a comparison between Chinese and other international students. Journal of Studies in International Education, 14, 389-405.

Lin, J-C. G., \& Yi, J. K. (1997). Asian international students' adjustment issues and program suggestions. College Student Journal, 31, 473-480.

Malcolm, I. G., \& McGregor, A. L. (1995). Worlds apart: An investigation of linguistic and cultural factors affecting communication between NESB and Edith Cowan University staff. Perth, Australia: Centre for Applied Language Research, Edith Cowan University.

Misra, R., \& Castillo, L. G. (2004). Academic stress among college students: comparison of American and international students. International Journal of Stress Management, 11(2), 132-148.

Misra, R., Crist, M., \& Burant, C. J. (2003). Relationships among the life stress, social support, academic stressors, and reactions to stressors of international students in the United States. International Journal of Stress Management, 10, 137-157.

Mori, S. (2000). Addressing the mental health concerns of international students. Journal of Counseling and Development, 78, 137-144.

Nahavandi, A., \& Malekzadeh, A. R. (1988). Acculturation in mergers and acquisitions. Academy of Management Review, 13, 79-90.

Nasir, M. (2012). Effects of cultural adjustment on academic achievement of international students. Journal of Elementary Education, 22, 95-103.

Nasrin, F. (2001). International female graduate students' perceptions of their adjustment experiences and coping strategies at an urban research university. Retrieved from ERIC databases (ED452336). 
Nilsson, J. E., Butler, J., Shouse, S., \& Joshi, C. (2008). The relationships among perfectionism, acculturation, and stress in Asian international students. Journal of College Counseling, 11(2), 147158.

Otlu, F. N. (2010). College adjustment of international students: the role of gender, acculturative stress, coping skills, cultural distance, and perceived social support (Master's thesis). Middle East Technical University, Institute of Social Science, Ankara.

Özçetin, S. (2013). Yükseköğrenim gören yabancı uyruklu öğrencilerin sosyal uyumların etkileyen etmenler (Master's thesis). Hacettepe University, Institute of Social Science, Ankara.

Özoğlu, M., Gür, B. S., \& Coşkun, İ. (2012). Küresel Eğgilimler Işı̆̆ında Türkiye'de Uluslararası Öğrenciler. Ankara: SETA.

Pedersen, P. (1991). Counseling international students. The Counseling Psychology, 19, 10-58.

Pirliyev, N. (2010). Yapısal eşitlik modelleri ile yabancı uyruklu öğrencilerin uyumu üzerine bir analiz (Master's thesis). Uludağ University, Institute of Social Science, Bursa.

Poyrazlı, S., Arbona, C., Nora, A., McPherson, R., \& Pisecco, S. (2002). Relation between assertiveness, academic self-efficacy, and psychosocial adjustment among international graduate students. Journal of College Student Development, 43, 632-643.

Poyrazlı, S., Kavanaugh, P. R., Baker, A., \& Al-Timimi, N. (2004). Social support and demographic correlates of acculturative stress in international students. Journal of College Counseling, 7, 73-82.

Poyrazl1, S., \& Lopez, M. D. (2007). An exploratory study of perceived discrimination and homesickness: A comparison of international students and American students. The Journal of Psychology, 141, 263280.

Poyrazlı, S., Thukral, R. K., \& Duru, E. (2010) International students' race-ethnicity, personality, and acculturative stress. International Journal of Psychology and Counseling, 2(2), 25-32.

Ramsay, S., Barker, M., \& Jones, E. (1999). Academic adjustment and learning processes: a comparison of international and local students in first-year university. Higher Education Research \& Development, 18(1), 129-144.

Redfield R., Linton R., \& Herskovits, M. J. (1936). Memorandum for the study of acculturation. American Anthropologist, 38, 149-152.

Rudmin, F. W. (2003). Critical history of the acculturation psychology of assimilation, separation, integration, and marginalization. Review of General Psychology, 7, 3-37.

Sandhu, D. S., \& Asrabadi, B. R. (1994). Development of an acculturative stress scale for international students: preliminary findings. Psychological Reports, 75(1 Pt 2), 435-448.

Sarason, I. G., \& Sarason, B. R. (1982). Concomitants of social support: Attitudes, personality characteristics, and life experiences. Journal of Personality, 50, 331-344.

Sawir, E., Marginson, S., Forbes-Mewett, H., Nyland, C., \& Ramia, G. (2012). International student security and English language proficiency. Journal of Studies in International Education, 16, 434-454.

Sodowsky, G. R., \& Plake, B. S. (1992). A study of acculturation differences among international people and suggestions for sensitivity to within group differences. Journal Counseling \& Development, 71, 53-59.

Srivastava, D. N., \& Tiwari, G. (1972). Manual for the Adjustment Inventory. Agra: Psychological Research Cell.

Sümer, S., Poyrazlı, S., \& Grahame, K. (2008). Predictors of depression and anxiety among international students. Journal of Counseling \& Development, 86, 429-437.

Tao, S., Dong, Q., Pratt, M., Hunsberger, B., \& Pancer, S. M. (2000). Social support: Relations to coping and adjustment during the transition to university in the People's Republic of China. Journal of Adolescent Research, 15, 123-144. 
Ward, C., \& Kennedy, A. (1995). Crossing Cultures: The Relationship between Psychological and Sociocultural Dimensions of Cross-Cultural Adjustment. In J. Pandey, D. Sinha, \& P. Bhawuk (Eds.), Asian contributions to cross-cultural psychology. New Delhi: Sage.

Ward, C., \& Kennedy, A. (1999). The measurement of sociocultural adaptation. International Journal of Intercultural Relations, 23, 659-677.

Wardlow, G. (1999). International students of agriculture in U.S. institutions precursors to academic success. Journal of Agricultural Education, 30, 17-22.

Williams, C. L., \& Berry, J. W. (1991). Primary prevention of acculturative stress among refugees: Application of psychological theory and practice. American Psychologist, 46, 632-641.

Yang, R. P., Noels, K. S., \& Saumure, K. D. (2005). Multiple routes to cross-cultural adaptation for international students: Mapping the paths between self-construal, English language confidence, and adjustment. International Journal of Intercultural Relations, 30, 487-506.

Ye, J. (2006). Traditional and online support networks in the cross-cultural adaptation of Chinese international students in the United States. Journal of Computer-Mediated Communication, 11(3), 863876.

Yeh, C. J., \& Inose, M. (2003). International students' reported English fluency, social support satisfaction, and social connectedness as predictors of acculturative stress. Counseling Psychology Quarterly, 16, 15-28.

Yuan, W. (2010). Investigating international student perceptions of adjustment through Q methodology. Intercultural Communication Studies, 19(2), 235-252.

Yusoff, Y. M. (2011). Self-efficacy, perceived social support, and psychological adjustment in international undergraduate students in a public higher education institution in Malaysia. Journal of Studies in International Education, 16(4), 353-371.

Yusoff, Y. M., \& Chelliah, S. (2010). Adjustment in international students in Malaysian public university. International Journal of Innovation, Management and Technology, 1(3), 275-278.

Zhang, Y. (2012). An examination of acculturative stress, perceived social support and depression among Chinese international students (Master's thesis). Syracuse University, Child and Family Studies - Theses.

Zimet, G. D., Dahlem, N. W., Zimet, S. G., \& Farley, G. K. (1988). The multidimensional scale of perceived social support. Journal of Clinical Psychology, 28, 191-193. 